\title{
Endemism due to climate change: Evidence from Poeciloneuron Bedd. (Clusiaceae) leaf fossil from Assam, India
}

\author{
Gaurav Srivastava* and R C Mehrotra \\ Birbal Sahni Institute of Palaeobotany, 53 University Road, Lucknow 226 007, India. \\ *Corresponding author.e-mail: gaurav_jan10@yahoo.co.in
}

\begin{abstract}
A fossil leaf resembling Poeciloneuron indicum Bedd. (Clusiaceae) is described from the Late Oligocene (Chattian 28.4-23 Myr) sediments of Assam. The modern analogue is endemic to the Western Ghats which is situated in the same palaeolatitude. Its presence, along with other known fossil records, indicates that the seasonality in temperature was less pronounced and CMMT (cold month mean temperature) was not less than $18^{\circ} \mathrm{C}$ with plenty of rainfall, in the region during the period of deposition. The study also indicates that the plant phenology is sensitive towards climate change. The present study is in congruence with the global data.
\end{abstract}

\section{Introduction}

Global climate during the Cenozoic displayed an overall cooling trend within which a series of warming and cooling rhythms occurred (Zachos et al. 2001). Of them, Late Oligocene was the time of global warming known as 'Late Oligocene Warming' (Zachos et al. 2001; Mosbrugger et al. 2005). The data needed for the reconstruction of land palaeoclimate is mainly based on terrestrial plants which are spatially fixed and therefore, have to be well adapted to local environmental conditions in order to survive and due to this their distribution is strongly controlled by their corresponding climate (Woodward et al. 2004). Among the land plants, endemic taxa are important because they grow in restricted environmental conditions (Jansson 2003). The fossil record of such taxa is also important to study their past distribution and sensitivity towards the climate change (Prasad et al. 2009).

The Makum Coalfield $\left(27^{\circ} 15^{\prime}-27^{\circ} 25^{\prime} \mathrm{N} ; 95^{\circ} 40^{\prime}-\right.$ $95^{\circ} 55^{\prime} \mathrm{E}$ ) which has an exposure of Late Oligocene
(Chattian 28.4-23 Ma) sediments (Srivastava et al. 2012b), is situated in the Tinsukia District, Assam (figure 1a) and is an important basin because of its diverse assemblage of plants (Awasthi and Mehrotra 1995; Mehrotra et al. 2003, 2009; Srivastava and Mehrotra 2010a, 2012; Srivastava et al. 2012a). Infact, there is no other Oligocene sedimentary basin in India which contains such a rich assemblage. The basin was situated at a low palaeolatitude, i.e., $\sim 10^{\circ}-15^{\circ} \mathrm{N}$ (Molnar and Stock 2009) at the time of deposition, when suturing between the Indian and Eurasian plates was not sufficiently complete to facilitate the plant migration (Srivastava and Mehrotra 2010b) and shows a deltaic, mangrove or lagoonal depositional environment (Awasthi and Mehrotra 1995; Mehrotra et al. 2003; Srivastava et al. 2012b). In the present communication, we have described a new leaf impression/compression whose modern analogue is endemic to the Western Ghats occurring in the same palaeolatitude. An attempt has also been made to explain the reasons for its endemism.

Keywords. Climate change; Clusiaceae; leaf; Makum Coalfield; Tikak Parbat Formation. 


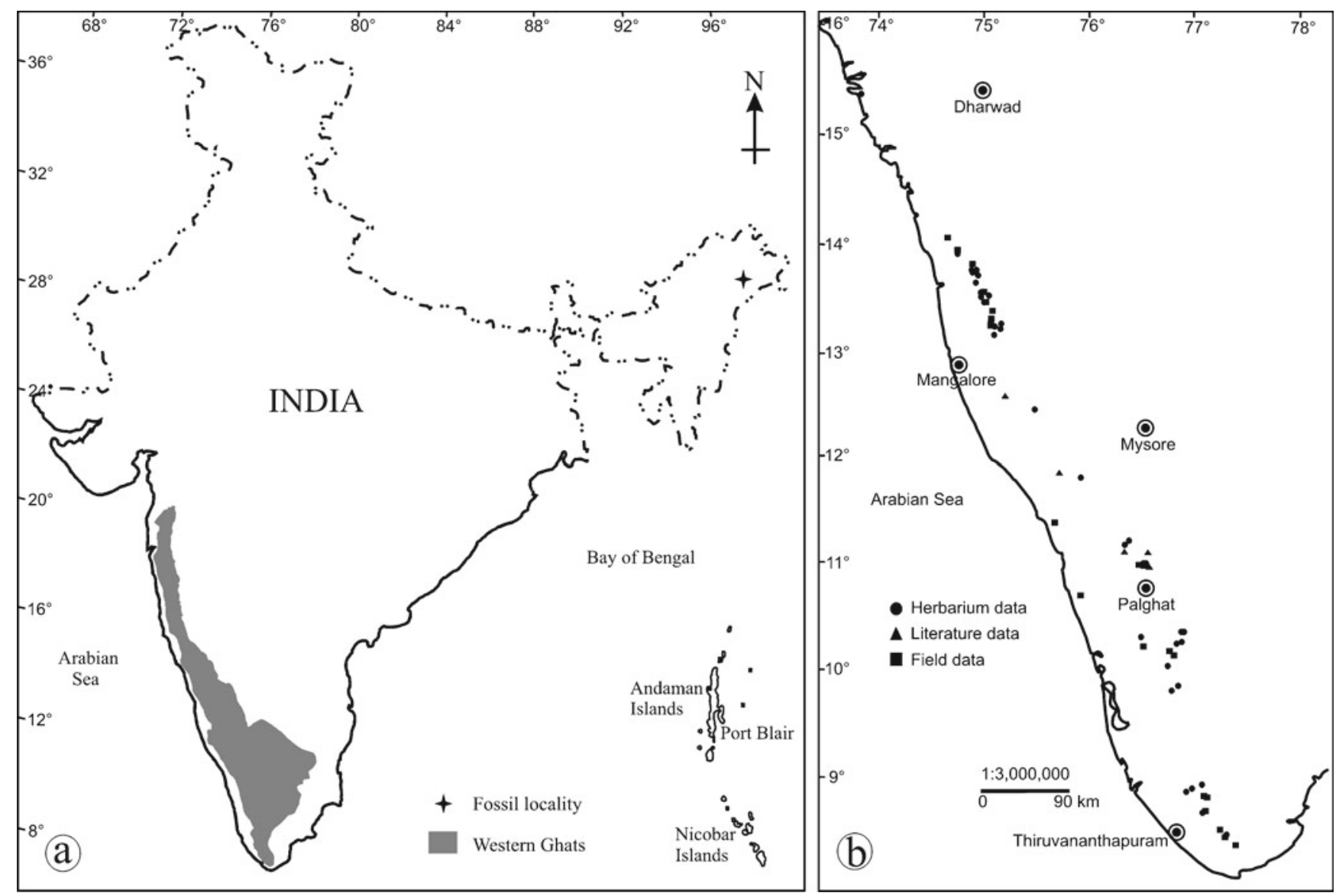

Figure 1. (a) Map of India showing fossil locality and Western Ghats. (b) Map showing modern distribution of Poeciloneuron indicum in the Western Ghats (Ramesh et al. 1997).

\section{Materials and methods}

The present fossil leaf was collected from the Tirap Colliery of the Makum Coalfield. After clearing the dust from the surface of the leaf, the fossil was photographed under low angle sunlight using 10 megapixel digital camera. The terminology used in describing the fossil leaf is based on Hickey (1973), Dilcher (1974) and Ellis et al. (2009). The identification of the fossil was made at the Central National Herbarium, Howrah and the Forest Research Institute, Dehradun after comparing it with herbarium sheets of the extant plants. The type specimen (holotype) bearing registration number BSIP 40060 is deposited in the museum of the Birbal Sahni Institute of Palaeobotany, Lucknow.

\section{Systematic description}

Family: Clusiaceae Lindl.

Genus: Poeciloneuron Bedd.

Poeciloneuron preindicum Srivastava and Mehrotra, sp. nov. (figure 2a, c)
Description: Leaf symmetrical, mesophyll, narrow oblong to lorate in shape; preserved lamina length $9.4 \mathrm{~cm}$ and maximum width $2.7 \mathrm{~cm}$ (near the middle); apex slightly broken, appearing attenuate; base symmetrical, normal obtuse; margin entire; texture coriaceous; petiole not preserved; venation pinnate, brochidodromous; primary vein moderate in thickness, slightly curved near the apical part; secondary veins 17 pairs visible, alternate to opposite, distance between two secondaries 0.2 $0.5 \mathrm{~cm}$, angle of divergence narrow to wide acute $\left(43^{\circ}-67^{\circ}\right)$, occasionally right angle $\left(81^{\circ}\right)$, upper pairs more acute than lower, moderately thick, uniform, joining superadjacent secondaries near the margin; intersecondary veins present, 1-2 in number, sometimes extended up to margin; tertiary veins random reticulate; marginal ultimate venation fimbriate; areoles well developed, oriented, predominantly quadrangular in shape.

Affinities: The important characters of the fossil, such as narrow oblong to lorate shape, attenuate apex, entire margin, coriaceous texture, brochidodromous venation, relatively numerous, closely spaced secondaries, angle of divergence of secondaries narrow to wide acute $\left(43^{\circ}-67^{\circ}\right)$, upper pairs 

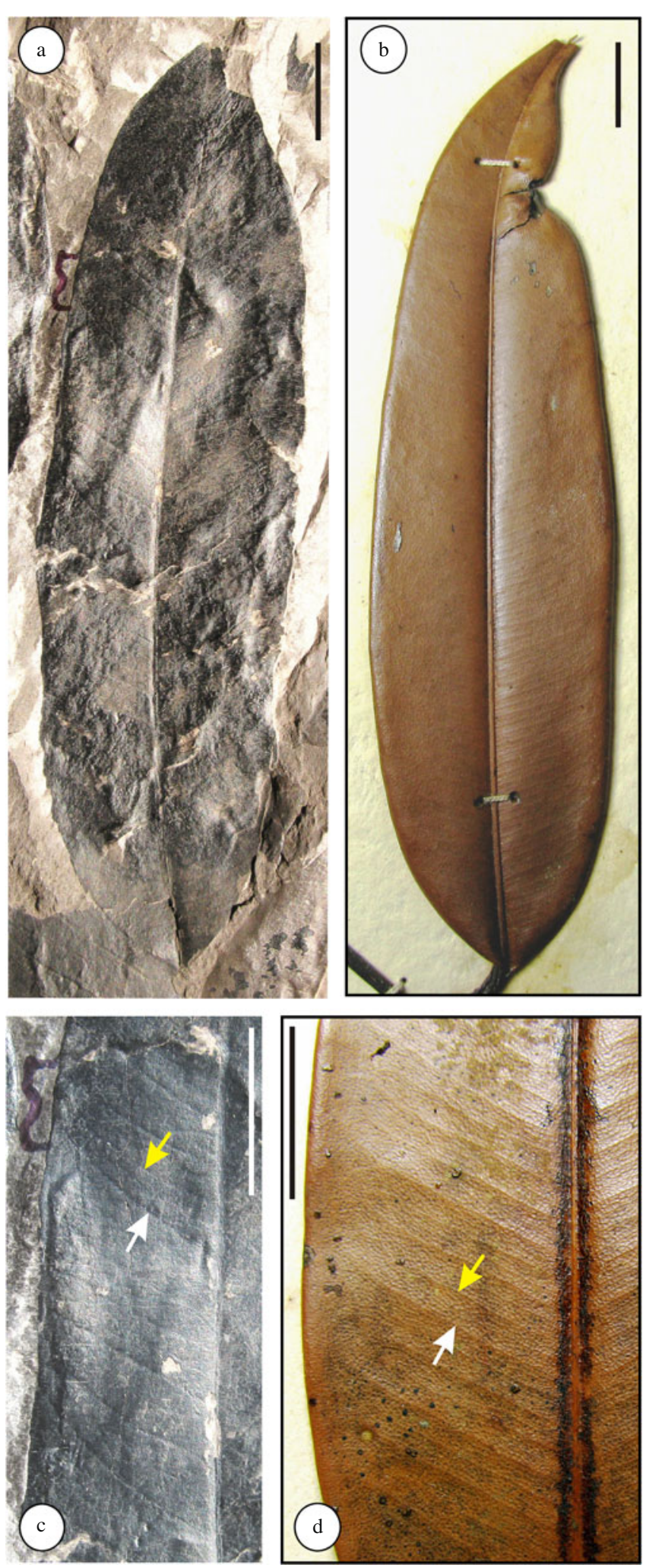

Figure 2. (a) Fossil leaf of Poeciloneuron preindicum Srivastava and Mehrotra, sp. nov. showing shape, size and venation pattern; (b) modern leaf of Poeciloneuron indicum showing similar shape, size and venation pattern as in the fossil; (c) middle portion of the fossil leaf showing intersecondary (yellow arrow) and secondary veins (white arrow); and (d) middle portion of the modern leaf showing similar intersecondary vein (yellow arrow) and secondary veins (white arrow) (scale bar $=1 \mathrm{~cm})$. more acute than lower, presence of very common occurrence of intersecondary veins (often one or more between each pair of secondary veins), running perfectly parallel to secondaries and sometimes extended upto the margin, random reticulate tertiary veins, fimbriate marginal ultimate venation, collectively suggest its close resemblance with the modern leaves of Poeciloneuron in general and $P$. indicum Bedd. (Herbarium Sheet No. FRI 52079) (figure 2b, d) in particular of the family Clusiaceae. A large number of herbarium sheets were examined at the Central National Herbarium, Howrah and the Forest Research Institute, Dehradun. However, during the herbarium consultation, some of the taxa within the family, viz., Mesua ferrea L., M. thwaitesii Planch. and Triana, Mammea americana L., Kayea assamica Prain, $K$. elegans King, K. floribunda Wall., K. paniculata Merr., K. racemosa Planch. and Triana and Garcinia atroviridis Giff. ex T. Anders. show apparent similarity to the fossil leaf but after close examination they were found different. In Mesua ferrea the secondary veins are more acute at the base in contrast to those found in the present fossil. In $M$. thwaitesii and Mammea americana shape is elliptic and secondary veins are more acute than those of the fossil. In Kayea assamica the leaf is elliptic and the secondary veins in the middle of the lamina are wide acute to right and at the base acute; all these characters are different from those of the fossil. In $K$. elegans, $K$. floribunda and $K$. racemosa, the venation is eucamptodromous, while in $K$. paniculata, the secondary veins are not narrow acute as found in the fossil. Moreover, tertiary veins in $K$. paniculata are percurrent in contrast to random reticulate in the present fossil. In Garcinia atroviridis secondary veins are more acute throughout the lamina, which is a feature different from the fossil.

There is no fossil leaf record of Poeciloneuron so far, therefore, a new species, Poeciloneuron preindicum Srivastava and Mehrotra, sp. nov. has been created, the specific epithet is after the modern species - Poeciloneuron indicum. The only other palaeobotanical record of this genus, of which we are aware, is the fossil wood of Poeciloneuron named P. palaeoindicum Srivastava and Awasthi (1996) from the Middle Miocene of Warkali beds, Kerala. Therefore, the present fossil seems to be the oldest fossil record of the genus. The fossil record of the family indicates that the Clusiaceae was well established by the Turonian (89.3-93.5 Ma) (Crepet and Nixon 1998) and in India its oldest fossil record is known from the Deccan Intertrappean sediments (Bande and Khatri 1980). Poeciloneuron is a monotypic genus (Rajkumar and Janarthanam $2007)$ and $P$. indicum is a large tree $(15-26 \mathrm{~m}$ in height) of evergreen forests endemic to the 
Western Ghats (figure 1a, b), where it is found between 700 and $800 \mathrm{~m}$ above sea level, i.e., in a very narrow belt, a little below the crest of the Ghats and is situated wholly on western slope which is exposed to monsoon winds (Pascal 1988).

Specific diagnosis: Leaf symmetrical, narrow oblong to lorate; apex appearing attenuate; base symmetrical, normal obtuse; margin entire; texture coriaceous; venation pinnate, brochidodromous; primary vein moderate in thickness, slightly curved near the apical part; secondary veins alternate to opposite, angle of divergence narrow to wide acute, occasionally right angle, moderately thick, uniform, joining superadjacent secondaries near the margin; intersecondary veins present; tertiary veins random reticulate; areoles well developed, oriented, predominantly quadrangular in shape.

Holotypus: Specimen no. BSIP 40060.

Horizon: Tikak Parbat Formation.

Locality: Tirap Colliery, Tinsukia District, Assam $\left(27^{\circ} 17^{\prime} 20^{\prime \prime} \mathrm{N}, 95^{\circ} 46^{\prime} 15^{\prime \prime} \mathrm{E}\right)$.

Age: Late Oligocene (Chattian 28.4-23 Ma).

Number of specimens studied: One.

\section{Discussion}

Phenology is an important aspect in plants because it plays a significant role in capturing the variable resources in different seasons for vegetative and reproductive growth (Schwartz 2003) which is essential for the fitness and survival (Rathcke and Lacey 1985; Reekie and Bazzaz 1987; Kozlowski 1992). Due to this, the phenology is considered to be the most important feature affected by climate change (Parmesan and Yohe 2003; Root et al. 2003; Walther et al. 2005; Menzel et al. 2006). The modern analogue of the fossil leaf, $P$. indicum, is endemic to the Western Ghats which is situated in the palaeolatitude of the fossil locality (figure 1a, b). The occurrence of the present fossil in the Makum Coalfield suggests that during the Late Oligocene, it was growing in the area having equable climatic conditions similar to those prevailing in the Western Ghats at present. The change in the climate and extinction of the fossil from northeast India may be attributed to the following reasons:

- Change in the latitude, i.e., from approx. $10^{\circ}-15^{\circ}$ to $27^{\circ} 17^{\prime} 20^{\prime \prime} \mathrm{N}$.

- Significant uplifting of the Himalayas during the Neogene (Chatterjee and Scotese 1999; Mehrotra et al. 2005).

- Recession of the Bay of Bengal to its present day boundary (Lakhanpal 1970).

Seasonality in temperature became more pronounced during the Neogene and most likely after the Miocene (Mehrotra et al. 2011) due to the aforesaid reasons and as a result $P$. indicum became extinct not only from the fossil locality but also from northeast India and is presently confined to the Western Ghats in between latitude $\sim 8^{\circ}-$ $15^{\circ} \mathrm{N}$ (figure $1 \mathrm{~b}$ ) which is similar to the palaeolatitude of the fossil locality. The climatic variables of fossil as well as modern localities of Poeciloneuron (table 1) indicate that disturbance in the phenology of the fossil due to the increased seasonality in temperature and change in latitude might be the two most likely reasons for its extinction from northeast India.

Among various families reported from the Makum Coalfield (Awasthi and Mehrotra 1995; Mehrotra et al. 2003, 2009; Srivastava and Mehrotra 2010a, 2012; Srivastava et al. 2012a, b), Annonaceae, Burseraceae, Clusiaceae, Combretaceae, Lecythidaceae, Myristicaceae and Rhizophoraceae are typical pantropical megathermal in nature (van Steenis 1962) which indicates that the CMMT (cold month mean temperature)

Table 1. Marked climatic variables in fossil and modern localities of Poeciloneuron indicum.

\begin{tabular}{|c|c|c|c|c|c|c|}
\hline Localities & $\begin{array}{l}\text { Latitude; } \\
\text { Longitude }\end{array}$ & $\begin{array}{c}\text { Mean annual } \\
\text { temperature } \\
\left({ }^{\circ} \mathrm{C}\right)\end{array}$ & $\begin{array}{l}\text { Mean temperature } \\
\text { of the warmest } \\
\text { month }\left({ }^{\circ} \mathrm{C}\right)\end{array}$ & $\begin{array}{c}\text { Mean temperature } \\
\text { of the coldest } \\
\text { month }\left({ }^{\circ} \mathrm{C}\right)\end{array}$ & $\begin{array}{l}\text { Mean annual } \\
\text { precipitation } \\
\quad(\mathrm{mm})\end{array}$ & $\begin{array}{l}\text { Relative } \\
\text { humidity } \\
(\%)\end{array}$ \\
\hline Mangalore & $\begin{array}{l}12^{\circ} 52^{\prime} \mathrm{N} \\
74^{\circ} 51^{\prime} \mathrm{E}\end{array}$ & 27.2 & 29 & 26.7 & 3291 & 80.2 \\
\hline Palghat & $\begin{array}{l}10^{\circ} 46^{\prime} \mathrm{N} \\
76^{\circ} 39^{\prime} \mathrm{E}\end{array}$ & 27.8 & 30.3 & 28.2 & 2058.6 & 78.8 \\
\hline Thiruvananthapuram & $\begin{array}{l}08^{\circ} 29^{\prime} \mathrm{N} \\
76^{\circ} 57^{\prime} \mathrm{E}\end{array}$ & 27.1 & 28.5 & 26.9 & 1839.3 & 84 \\
\hline Climate range & & $27.1-27.8$ & $28.5-30.3$ & $26.7-28.2$ & 1839.3-3291 & $78.8-84$ \\
\hline $\begin{array}{l}\text { Tinsukia } \\
\text { (fossil locality) }\end{array}$ & $\begin{array}{l}27^{\circ} 17^{\prime} 20^{\prime \prime} \mathrm{N} ; \\
95^{\circ} 46^{\prime} 15^{\prime \prime} \mathrm{E}\end{array}$ & 22.7 & 27.6 & 15.8 & 2224.4 & 78.4 \\
\hline
\end{tabular}


was not less than $18^{\circ} \mathrm{C}$. Similarly, Fabaceae whose abundance and richness covary with temperature (Punyasena et al. 2008), is the most dominant family in the Makum Coalfield (Srivastava and Mehrotra 2010a) and indicates a warm climate. The presence of Avicenniaceae and Rhizophoraceae indicates the deltaic, mangrove or lacustrine environment of deposition of coal seams and associated sediments in the Makum Coalfield (Awasthi and Mehrotra 1995). The presence of abundant palms like Nypa (Mehrotra et al. 2003) renders further evidence of a coastal plain environment where both temperature and humidity remained high throughout the year (Tomlinson 1990) i.e., less seasonality in temperature. The recent CLAMP (climate leaf analysis multivariate program) analysis $\left(\mathrm{MAT}=26.09 \pm 2.7^{\circ} \mathrm{C}, \mathrm{WMMT}=27.85 \pm 3.3^{\circ} \mathrm{C}\right.$, $\mathrm{CMMT}=20.66 \pm 4.3^{\circ} \mathrm{C}, \mathrm{MAP}=2460 \pm 614 \mathrm{~mm}$ and $\mathrm{RH}=76.6 \pm 12.6 \%$ ) from the same horizon also indicates less seasonality in temperature (Srivastava et al. 2012b). The warm and humid climate in the Makum Coalfield during the deposition of the sediments is not surprising, as the fossil locality was at $10^{\circ}-15^{\circ} \mathrm{N}$ palaeolatitude, i.e., in tropics during the Late Oligocene (Molnar and Stock 2009) and it has been observed that not only the regional, but also the global climate during the Late Oligocene was warm (Zachos et al. 2001; Mosbrugger et al. 2005). The result of the present study is in congruence with the above records.

\section{Acknowledgements}

The authors are thankful to the authorities of Coal India Limited, Margherita for permitting them to collect the plant fossils. They are grateful to the Director, Botanical Survey of India, Kolkata and the Forest Research Institute, Dehradun for permitting them to consult the herbarium. Thanks are also due to Dr N C Mehrotra, Director, Birbal Sahni Institute of Palaeobotany, Lucknow for providing necessary facilities and permission to publish this work.

\section{References}

Awasthi N and Mehrotra R C 1995 Oligocene flora from Makum Coalfield, Assam, India; Palaeobotanist 44 157-188.

Bande M B and Khatri S K 1980 Some more fossil woods from the Deccan Intertrappean beds of Mandla District, Madhya Pradesh, India; Palaeontographica B 173(4-6) 147-165.

Chatterjee S and Scotese C R 1999 The breakup of Gondwana and the evolution and biogeography of the Indian plate; Proc. Indian Nat. Sci. Acad. 65A 397-425.

Crepet W L and Nixon K C 1998 Fossil Clusiaceae from the Late Cretaceous (Turonian) of New Jersey and implications regarding the history of bee pollination; $\mathrm{Am}$. J. Bot. 85(9) 1122-1133.

Dilcher D L 1974 Approaches to the identification of angiosperm leaf remains; Bot. Rev. 40 1-157.

Ellis B, Daly D, Hickey L J, Johnson K R, Mitchell J, Wilf P and Wing S L 2009 Manual of Leaf Architecture (Ithaca, New York: Cornell University Press).

Hickey L J 1973 Classification of the architecture of dicotyledonous leaves; Am. J. Bot. 60 17-33.

Jansson R 2003 Global patterns in endemism explained by past climatic change; Proc. Biol. Sci. 270 583-590.

Kozlowski J 1992 Optimal allocation of resources to growth and reproduction: Implications for age and size at maturity; Trends in Ecol. Evol. 7 15-18.

Lakhanpal R N 1970 Tertiary flora of India and their bearing on the historical geology of the region; Taxon 19 675-694.

Mehrotra R C, Bera S K, Basumatary S K and Srivastava G 2011 Study of fossil wood from the MiddleLate Miocene sediments of Dhemaji and Lakhimpur districts of Assam, India and its palaeoecological and palaeophytogeographical implications; J. Earth Syst. Sci. 120(4) 681-701.

Mehrotra R C, Dilcher D L and Lott T A 2009 Notes on elements of the Oligocene flora from the Makum Coalfield, Assam, India; Palaeobotanist 58 1-9.

Mehrotra R C, Liu Xiu-Qun, Li Cheng-Sen, Wang Yu-Fei and Chauhan M S 2005 Comparison of the Tertiary flora of southwest China and northeast India and its significance in the antiquity of the modern Himalayan flora; Rev. Palaeobot. Palynol. 135 145-163.

Mehrotra R C, Tiwari R P and Mazumder B I 2003 Nypa megafossils from the Tertiary sediments of northeast India; Geobios 36 83-92.

Menzel A et al. 2006 European phenological response to climate change matches the warming pattern; Glob. Change Biol. 12 1969-1976.

Molnar P and Stock J M 2009 Slowing of India's convergence with Eurasia since $20 \mathrm{Ma}$ and its implications for Tibetan mantle dynamics; Tectonics 28 TC3001.

Mosbrugger V, Utescher T and Dilcher D L 2005 Cenozoic continental climatic evolution of Central Europe; Proc. Nat. Acad. Sci. USA 102 14,964-14,969.

Parmesan C and Yohe G 2003 A globally coherent fingerprint of climate change impacts across natural systems; Nature 421 37-42.

Pascal J P 1988 Wet Evergreen forests of the Western Ghats of India (Pondichery: Inst. Fr. Pondichery).

Prasad V, Farooqui A, Tripathi S K M, Garg R and Thakur B 2009 Evidence of Late Palaeocene-Early Eocene equatorial rain forest refugia in southern Western Ghats, India; J. Biosci. 34(5) 777-797.

Punyasena S W, Eshel G and McElwain J C 2008 The influence of climate on the spatial patterning of neotropical plant families; J. Biogeogr. 35 117-130.

Rajkumar S and Janarthanam M K 2007 Agasthiyamalaia (Clusiaceae), a new genus for Poeciloneuron pauciflorum, an endemic and endangered tree of Western Ghats, India; J. Bot. Res. Inst. Texas 1(1) 129-133.

Ramesh B R, Pascal J P, Nougier C and Datta R 1997 Endemic Tree Species of the Western Ghats India (French Institute of Pondicherry, CD-ROM).

Rathcke B and Lacey E P 1985 Phenological patterns of terrestrial plants; Ann. Rev. Ecol. Evol. Syst. 16 179-214.

Reekie E G and Bazzaz F A 1987 Reproductive efforts in plants; Am. Naturalist 129 876-919.

Root T L, Price J T, Hall K R, Schneider S H, Rosenzweig $\mathrm{C}$ and Pounds J A 2003 Fingerprints of global warming on wild animals and plants; Nature 421 57-60. 
Schwartz M D 2003 Phenology: an integrative environmental science (Dordrecht, The Netherlands: Kluwer Academic).

Srivastava G and Mehrotra R C 2010a New legume fruits from the Oligocene sediments of Assam; J. Geol. Soc. India 75 820-828.

Srivastava G and Mehrotra R C 2010b Tertiary flora of northeast India vis-à-vis movement of the Indian plate; Geol. Soc. India Memoir 75 123-130.

Srivastava G and Mehrotra R C 2012 Oldest fossil of Semecarpus L.f. from the Makum Coalfield, Assam, India and comments on its origin; Curr. Sci. 102(3) 398-400.

Srivastava G, Mehrotra R C and Bauer H 2012a Palm leaves from the Late Oligocene sediments of Makum Coalfield, Assam; J. Earth Syst. Sci. 121(3) 747-754.

Srivastava G, Spicer R A, Spicer T E V, Yang J, Kumar M, Mehrotra R and Mehrotra N 2012b Megaflora and palaeoclimate of a Late Oligocene tropical delta, Makum Coalfield, Assam: Evidence for the early development of the South Asia Monsoon; Palaeogeogr. Palaeoclimatol. Palaeoecol. 342-343 130-142.

Srivastava R and Awasthi N 1996 Fossil woods from Neogene of Warkalli beds of Kerala coast and their palaeoecological significance; Geophytology 26(1) 89-98.

Tomlinson P B 1990 The Structural Biology of Palms (Oxford: Clarendon Press).

van Steenis C G G J 1962 The land-bridge theory in botany; Blumea 11(1) 235-372.

Walther G R, Berger S and Sykes M T 2005 An ecological 'footprint' of climate change; Proc. Biol. Sci. 272 14271432.

Woodward F I, Lomas M R and Kelly C K 2004 Global climate and the distribution of plant biomes; Phil. Trans. R. Soc. Lond. B 359 1465-1476.

Zachos J, Pagani M, Sloan L, Thomas E and Billups K 2001 Trends, rhythms, and aberrations in global climate $65 \mathrm{Ma}$ to present; Science 292 686-693. 